\title{
Hermeneutic Analysis on "School and University" Articles' Topics on the Russian Global Net
}

\author{
Elena A. Makarova ${ }^{1, *}$, Elena L. Makarova ${ }^{2}$, Ludmila N.Seliverstova ${ }^{3}$ \\ ${ }^{1}$ Don State Technical University, Rostov-on-Don, Russian Federation \\ ${ }^{2}$ Southern Federal University, Taganrog, Russian Federation \\ ${ }^{3}$ Southern Federal University, Rostov-on-Don, Russian Federation
}

Received November 11, 2019; Revised January 17, 2020; Accepted February 7, 2020

Copyright $\subset 2020$ by authors, all rights reserved. Authors agree that this article remains permanently open access under the terms of the Creative Commons Attribution License 4.0 International License

\begin{abstract}
The article considers analysis of media texts of the Russian Internet on school, university and students topics published on the network in the period from the mid-nineties to the present day using the hermeneutical method. As a result of the analysis, it was possible to find out that the images of school and university as educational institutions, schoolchildren, students, teachers of secondary and higher schools in the media texts of different Internet resources are identical in content, but different in the form, i.e. set of language tools. The same historically, culturally and socially conditioned problems in education are presented in the standard Russian language on the websites of official media (for example, Teacher's newspaper), with the widespread use of youth slang in comments and personal blogs (for example, in studroom.ru) and in the profanity on marginal sites that deny the values and taboos of both the real and virtual worlds (for example, udaff.com). Among the main components of the image of Russian education in the last two decades, the following can be distinguished: there is a bias towards material values with the loss of spiritual values among young people; there is an active search for a new value system; there is a drop in the level of education in schools; the prestige of higher education is maintaining; there is commercialization as a part of the educational process in the educational sphere in the process of which education is deteriorating; there is a backlog of schools and universities from the real needs of society and the state; there is a low status of the teaching profession.
\end{abstract}

Keywords Hermeneutic Analysis, Media Text, Schoolchildren, Students, Internet, School, University, Teacher

\section{Introduction}

The end of the twentieth century in Russia was marked by many important events, including the beginning of the Internet era. In 1994, the .ru-domain was officially registered. The Russian Internet (Runet) gained a start in life, opened up unlimited opportunities in the field of communication for residents of the country, and has become a kind of a multifaceted cultural phenomenon and profitable business. At the same time, unlimited possibilities are fraught with many difficulties, such as the absence of any signs indicating age restrictions when searching websites, obsessive advertising of goods and services, imposing of certain needs, lifestyles, and worldviews.

The global network space has become available to all social and age groups of Russian population. The greatest activity in mastering the Internet is shown by adolescents and youth, while their parents and teachers are not yet sufficiently aware of both the possibilities of the Internet and the new risks and threats of the Web [1]. Today, the Internet is a space in which new meanings, new cultural values, and norms of interaction are constantly being constructed. A new culture of the digital world is being born in a dialogue between different communities, often sharing opposing beliefs, interests and worldviews.

In this regard, it seems important to consider the media texts of the Russian Internet on school and student topics from the mid-nineties to the present.

The purpose of the study is to trace the transformation of patterns and behaviors in the Russian educational environment over the past 30 years on the basis of online publications, to get a general picture of modern education in Russia and to predict trends in its development in the near future. 


\section{Materials and Methods}

The material of the study was the Russian Internet and its sites containing media texts on the school and university topics. The materials of the websites have been analyzed, Teachers' Newspaper network publication, the educational media project on the formation of Newton New, the educational journal School of Life.ru, the online magazine Our Youth, the personal website studroom.ru, and the website udaff.com of the Russian alternative subcultures' representatives whose nickname is "bastards" being among them. In the framework of this study, media texts were examined to represent the image of the main participants in the educational process - a teacher and a student, as well as the educational institution as it is (a school and a university). The attempt made is not the first and the authors are not the pioneers.

Media education (from Latin media - means) - a direction in pedagogy advocating the study of "Patterns of mass communication (press, television, radio, cinema, video, etc.). The main objectives of media education are to prepare a new generation for life in modern information digital society, for perception of various information, also to teach students to understand it, to realize the consequences of its impact on the psyche, to master the methods of communication based on non-verbal forms of communication through technical means" [2:555].

"Media education, then, is one of the few instruments which teachers and students possess for beginning to challenge the great inequalities in knowledge and power which exist between those who manufacture information in their own interests and those who consume it innocently as news or entertainment" [3: 11].

Media education is associated with knowledge of how media texts are created and distributed, and with the development analytical abilities their content is interpreted and evaluated (whereas media studies are usually associated with practical work on creating media texts). As media education (media education), and the study of media (media studies) are aimed at achieving goals media literacy [4: 9494].

The images of school and university in the cinema are presented in the works of Russian and foreign scholars (U. Pertseva, M. Khaliullina [5], A. Sayer [6], N. Tucker [7] etc.).

The media image of a modern Russian teacher was analyzed in the works of A.A. Machenin [8], Y.V. Soldatkina [9], A.Y. Shakhanskaya [10] and other scholars who identify the problem of the ubiquitous critical media perception of a teacher [9:274], reducing the prestige and popularity of a positive image of a teacher and a teaching profession as a whole in the media [11:25].

As the main research method, a comparative hermeneutic analysis of Russian Internet media texts (1995-2019) related to this topic (including analysis of stereotypes, ideological analysis, identification analysis, iconographic analysis, etc.) was used. In the process of analysis, we relied on the methodology and to keywords of media education such as "media agencies", "media / media text categories", "media technologies", "languages media " (media languages), " media representations" and "media audiences" (Web sites readers), since all these concepts are directly related to the hermeneutic analysis of media texts.

Media literacy is an ability to master, interpret / analyze and create media texts" [12].

Media languages are the way in which the meaning of the media texts is conveyed to the audience. Each medium has its own language or grammar that works to convey the meaning in a unique way. 'Audience' is the term used to describe a large number of unidentifiable people united by their participation in media use [13]. Those audiences have different preference or motivation in using the media [14].

\section{Discussion}

If the twentieth century was called the one of information civilization, the twenty-first century should be named digital information era; this fact definitely requires timely reflection [15]. In this regard, issues of media texts analysis providing means of searching and organizing knowledge in digital format are relevant. Today, there are many methods of text analysis (linguistic, logical, systemic, structural, etc.), it is necessary to highlight the philosophical - phenomenological and hermeneutical methods of text analysis among them. This article attempts to make a comparative hermeneutic analysis of the media texts of the Russian Internet, so we dwell on the basic principles of the hermeneutic approach.

The founder of philosophical hermeneutics is the German philosopher F. Schleiermacher, who called it "the doctrine of the art of understanding" (Kunstlehre des Verstehens). The universality of understanding for F. Schleiermacher is limited to one single law, the so-called hermeneutic circle: the whole can be understood when we study its constituent parts, and any part can be studied only in connection with the whole [16: 328]. The interpreter of the text should take a look at the whole text, uniting and enriching the meanings around it. When interpreting, the following triad should be taken into account: language-text-author. The main role is played by the text collecting all linguistic and extra-linguistic elements into a single whole. F. Schleiermacher expanded the boundaries of the text understanding by including extra-linguistic factors, the situation of the text, the historical context, the personality of the author, etc. In other words, the texts began to reflect the author's intentions (designs), lifestyle and the historical era. According to F. Schleiermacher, to understand a text means to recreate the perception (Wiedererleben des Bewusstseins) of the historical moment to which it refers. 
For another German philosopher H. G. Gadamer, hermeneutics is more an event (Geschehen) than understanding. It is a special kind and way in which the culturally determined interconnection of traditions, norms, and customs is preserved and developed. H.G. Gadamer argues that hermeneutics as an art of understanding cannot be limited by the scientific method [17]. Understanding (Verstehen) is an experience of truth comprehension that characterizes human life. Raising understanding from a methodological level to an ontological one, H.G. Gadamer follows M. Heidegger, who interpreted understanding as an "existential" event [18]. At the same time, the thinker emphasized the linguistic component of the hermeneutic event, namely, the existence of the language system and the individuals' participation in it. By reading, interpreting and transmitting traditional texts, we connect our present life with the socio-cultural tradition [19]. In addition to the aforementioned philosophers, hermeneutics as an ontological theory of language was developed in the works of M. Heidegger, J. Habermas, K.O. Apel, P. Ricoeur, E. Betty, H. Lipps and others.

Russian researchers have repeatedly resorted to hermeneutical analysis of texts, including media texts: animated media texts [20], Soviet feature films, reality shows [21], and literary works in verses by A.S. Pushkin's "Eugene Onegin" [22], the stories by A.P. Chekhov, posters and professional photographs [23].

The time period considered in the articles is associated with the construction of the information society in Russia. The last decade can be described as a period of the Internet spread on the whole territory of Russia; a global network has become available to everyone. Young people are particularly interested in this phenomenon development. According to sociological studies, in 1998 only $20 \%$ of Russian teenagers used the Internet, in 2012 there were $93 \%$, nowadays teenagers do not just use the Internet, "they actually live within it" [24]. At the end of the XX and beginning of the XXI centuries, schoolchildren and students got their social experience primarily through communication with peers, parents, teachers and instructors. Today, the Internet is becoming the main source of information significant for children, adolescents, and young people. Meanwhile, the role of the passive consumer of information is definitely changing to its active creator and promoter. The younger generation seeks to establish themselves as active creators of the information space. They have knowledge and possibility to independently create their own personal sites, pages in social networks, presentations, etc.

\section{Research results}

The main characteristics of this historical period: school-related media texts made their appearance in the Russian global network in 1995, when the Teacher's newspaper website was created [http://ug.ru/archive]. As paradoxical as it may seem, it was Teacher's Newspaper that became the first offline media on the Internet in our country. Note that at the moment it is difficult to draw the line between electronic and print media, since their vast majority is widely presented on the net. The year of 1997 was the starting point in the development of the Russian Internet, as it was in this year that the foundation for the opening of many Russian-language resources that publish media texts on relevant topics was laid. Such topics of study as school and university were considered to be universal and, accordingly, have been widely represented in the media texts within the last twenty years.

At the beginning of the period under consideration, there was a deep economic and social crisis in the country and, as a result, the impoverishment of the population majority to the degree that state employees (teachers, doctors) were literally forced to survive, many had to give up their professions. Media texts of the mid-90s painted a very ugly picture of general decay and chaos: "... school buildings are flaky, dirty playgrounds, neglected green spaces and parks. Just look at all this garbage littering the school yards: chewing gum wrappers, cookies and candy wraps. What is wrong? Children didn't use to litter, but now they can't find a trash can. So schoolchildren are dumping everything on the ground... Economic crisis and social turmoil is accompanied by a decline in the culture of younger generation" [25].

No wonder the 90s were called the "dashing 90s": redistribution of property, rampant crime. Democratization swept all spheres of life, including school, "destroying not only leftovers of a totalitarian society, but also some valuable experience and traditions of quality education. In the early $90 \mathrm{~s}$, the mandatory state minimum of school subjects was canceled. Schools were given the right to choose textbooks and programs that spawned at an enormous speed. Created in haste, not previously tested, not supported by serious research, new educational systems wreaked havoc in education. The continuity of elementary, secondary and high school education was broken, the level of training decreased" [26]. University education in the 1990s in Russia was in a dramatic situation, too. Educational programs did not comply with the requirements of the labor market, educational standards were destroyed, many sectors of the economy were in decline, demand for technical majors was sharply reduced, outdated teaching technologies and methods prevailed, etc.

At this time, the stratification of society was clearly polarized: a class of the very rich, the so-called 'new Russians' on the one pole, and the poor on the other pole in the complete absence of the middle class. "Today, anarchy reigns everywhere. And education is no exception. Children who do not need anyone are tormented. What is wrong with education in our society? For "elite children" their financially well-off parents create gymnasiums, colleges, and lyceums, and for children from dysfunctional families who are not needed by the society 
anymore there's nothing" (from the blog of the headmaster of Nikolsk boarding school for socially disadvantaged children, the deputy of the Kostroma City Duma Boris Chernov) [27].

Since 2009, the issue of a unified state exam (USE) has not lost its relevance in media texts on school topics. Some people see it as the reason for the collapse of Soviet school traditions and demand cancellation; others analyze the shortcomings and require improvement. But everyone agrees that today's exam does not meet modern needs. A young teacher regularly publishes his articles in many educational online resources and asks questions: "If a student is an active doer in the educational process, and the educational institution provides educational services, then what does the exam check? And what should it?" [28].

Both in the 90s and today, the education sector in Russia has been in a difficult situation. Educational programs do not meet the requirements of the market, some educational standards supersede others, this makes the content of education a little different, obsolete teaching technologies and corruption certification schemes for schoolchildren and students also prevail. The gap "between school and life tasks is obvious. A school is a school, and life is life, and these two worlds do not intersect in the minds of children. Children perceive school as their work, in which they need to achieve certain success, and do not understand what to do in their own life" [29]. The same can be said about students who, during their studies, "just do what they are asked about and save energy for more important things. They are barely eighteen, but they already understand how inadequate the education system is to modern realities" [30].

In the mid-90s, for the most part, the media broadcast the image of a poor teacher in a shabby school building requiring long repair. At the same time, as an exception to the rule, the image of an enthusiastic teacher is presented. For example, in the archive on the site of Teacher's Newspaper, S. Ivanova describes "an amazing rural boarding school where teachers live and study for a month without leaving the place". The author writes: "This school like all Russian schools of our days experiences the most severe pressure from the emerging market relations, the efforts of educating enthusiasts led by a wonderful headmaster, a biology teacher, turned his long-repaired building into the one equipped with everything necessary for a modern educational institution, united by an amazing concept - Beauty around us and inside us! And this is in the era of "survival", when everyone is just busy with how to make money and live from hand to mouth" [31].

The demographic situation in the period under review (a sharp decline in the birth rate in the 90s) could not but affect the school. This problem was most clearly manifested in rural schools. Here is one of the typical images of a rural school:
"... not enough students in classes, tired teachers and indifferent headmasters ... common problems: there are fewer first-graders every year as children are not eager to learn. Most parents work in cities, children stay at grandmothers' ... most rural graduates are not aware that their future is predetermined. It will develop according to the plan - after serving in the army, they work in the security agency or police forces. For the girls marriage to one of their former classmates is not a good chance. And those who have children do it out of despair, having nothing more to do. They are children who do not have dreams" [32].

The analyzed period accounts for the annexation of the Crimean peninsula to Russia. A lively discussion of teacher-historians regarding the interpretation of events in modern Russian history in the absence of official materials in school textbooks has expanded on the Internet. In one of the media texts, a character of an 'opposition' teacher is presented: "It was after the Crimean events of 2014 , or rather because of them, that I left school, where I worked for almost 20 years. I could not explain to children with good conscience why Crimea is now "ours" and we, the Russians, have all the rights for this territory. Because for me more important than imperial ambitions is the sovereignty of states, compliance with the signed agreements and international law. I participated in the protest movement and did not support Russia's foreign policy in Ukraine. Therefore, the headmaster required my resignation; I had to leave school" [33].

It is difficult to give a certain integral characteristic of media texts on school and student topics, published on the Internet since everyone can publish their text on the network. Now everyone can write - students and schoolchildren in their own blogs, teachers, scientists, researchers, education scholars, common people, in a word, everyone who would like to speak out on a given topic. Moreover, to reveal authorship is not always possible, since published materials can be anonymous, author can use a nickname, etc.

Many authors of the media texts of the analyzed websites paint a modern picture of general commercialization in the educational environment, which is directly related to general trends in Russian society. The ideas of altruism, of work for charity are no longer relevant; the idea "any work should be paid" is cultivated. Relations between students are becoming exclusively "business": "make money on classmates", "organize barter" (complete assignments can be exchanged for money or another task), this is not considered shameful, but means "being smart" [studroom.ru].

In the media texts under consideration, the topic of corruption is also widely represented, more precisely, the problem of society accepting corrupt behavior in the field of higher education as a norm, as it is in many other areas of life. Moreover, corruption does not mean just bribery. Among students and, to a greater extent, graduates of Russian universities, cheating on an exam, downloading 
completed assignments from the network, or buying them for money is considered normal. And this is ascertained not only by sociologists based on the results of their research [34], but also by the students themselves in their blogs. They do not discuss the need to write cheat sheets as an alternative to preparing for the exam, but raise the question "write prompts on their own or chip in the whole group and order them from professionals" [studroom.ru].

Young people represented in media texts during the analyzed period can be divided into "lost generation" (1990-2005) and "generation Z" (2005 - to date). These are young people whose maturation occurred in a given period of time.

In the 1990s, "in fact, the whole society broke down, together with its moral and ethical foundations ..., in the conditions of complete value debunking ... the generation of the 1990s was deprived of an elementary idea of what is good and what, on the contrary, is evil ... It seemed to many that the generation that had grown up when the ideals for young men were the dubious "heroes" of criminal battles and chronicles, and for many girls, the career of a confused or weak woman with a rich lover was the ultimate dream " [35]. Among the cult films of that time were "Intergirl" by P. Todorovsky (1989), "Brigade" by A. Sidorov (2002), "Gangster Petersburg" by V. Bortko (2000), etc. However, this generation is "now at the helm" ... They deal with finance and solve political problems ... and have got the right to host the 2014 Olympic games [35].

Generation $\mathrm{Z}$ is the so-called "Internet generation." The joke is they were born with the help of gadgets. "For them, leaving a house without a mobile phone is like going out naked ... a new generation adheres to the principle of living in the present time. They want to enjoy life and have nothing to worry about. The main goal of life is "to be happy." Moreover, happiness for them is associated primarily with physical and psychological comfort, as well as personal freedom. They have many requests, but little desire to take responsibility and to make work a life priority. ... These people are citizens of the world, and therefore traveling around the world is one of their main values. The second most important value is the preservation of health and fitness. Next social activity and fashionable hobbies come. They also care about environmental protection, are interested in art and innovations, they are happy to accept other people's ideas in order to generate their own ones ... They are able to carry out a large number of tasks at the same time, since they are used to listening to music from childhood and upload content, and type text, and read social media feed, and chat with friends, and at the same time absorb their lunch" [26].

The presented picture as a whole coincides with that obtained by sociologists in 2017 according to the results of an all-Russian study conducted by the Higher School of Economics NRU - "The Image of Desired Russia: Values of Russian Students". As the researchers noted "current students are not very different from their fathers and mothers ... Material values of young people are in the foreground (of course, spiritual development is also important, but, as it turns out, not paramount). This is largely because parents of modern students - typical youth of the 90s, who survived severe hardships and lack of those very basic bare necessities - are trying to give their children all the best, instead of setting them up to work, making them independently achieve their goals and adding difficulties to whatever problems they have" [36].

The structure of media texts published on the Internet is characterized by the nonlinearity of information deployment, hypertextuality, multimedia, and multicode [37]. The recipient of the media text on the Internet can at any time go from the original text through the links provided to another text, thereby expanding the field of perception. Media texts on the Internet, in addition to numerous links, usually include a visual component, often sound and video texts, in other words, elements of different semiotic systems.

Schematically, the structure, plot, representativeness, ethics, features of genre modification, iconography, characters of characters of media texts on school and students topics on the Internet in the period from 1995 to the present date can be represented as follows:

a) the place and duration of the media texts: geography is represented in the widest possible way: from schools in the rural outback to modern educational institutions in large cities;

b) the situation typical of these media texts, household items: schools and universities in poor condition, requiring repair at the end of the 20th century. and in contrast to them, modern well-equipped private schools, research centers, scientific laboratories at major metropolitan universities nowadays;

c) genre modifications of school-school subjects: author or collective interactive articles. On the websites, informational texts are presented, as a rule, in the "news" section, analytical texts - in the "article" section and artistic and journalistic - in the "history", "diary" sections, etc.;

d) (stereotypical) methods of depicting reality, typology of characters (character traits, clothing, physique, vocabulary, facial expressions, gestures of characters, presence or absence of a stereotypical manner of representing characters in these media texts): typical student images can be distinguished:

- "nerd" is always the best performer, sits in front of the class, does not skip lessons;

- initiative, enterprising, quick-witted, not missing the opportunity to make money in class and take advantage of classmates;

- representative of the "golden youth" - children from high income families or University professors' children.

It should also be noted the emergence of a new image of the leader in the field of education. If earlier this type, as a rule, used to be an experienced and respected teacher 
with great experience and background, now the image of a teacher-manager has been formed. He is not busy in the educational process, but in managing the whole school.

School teacher:

- a mentor, educator who, in addition to knowledge of the subject, gives an idea of life, of what is good and what is evil;

- an enthusiastic teacher, with a modern life outlook, conscientious, passionate about his job;

- sportsman, who got to school by chance, usually with an unfinished higher education.

The idea of school is connected with the image of a student in a school uniform. In the early 90s, the first reform in schools was associated with the abolition of a uniform. The website "Nostalgia for the 90s" recalls: "The same brown dresses suddenly became a symbol of total unification and suppression of personality. At school meetings, the majority voted for the uniform banning from school. The most desperate schoolchildren fought for their tight to wear jeans in class. Only very experienced teachers could force schoolgirls to the wash off their makeup or to remove golden jewelry". "Clothes at school became flashy and awkward, from fancy dresses to tracksuits. Girls were wearing bright and aggressive makeup, and finally they got the right to wear trousers at school" [38]. The topic of school uniforms is relevant on the Internet throughout the study period. 10 years after the cancellation of the uniform it suddenly became an attribute of "elite" schools (gymnasiums, lyceums), and by 2013 everything had returned back to normal use of uniforms, in vast majority of Russian schools the school uniform again became a mandatory requirement, and its pros and cons were widely discussed on the Internet. It is true that the experience of Western countries is now considered as a positive example, but somehow they keep silent about the school uniform wearing traditions of the Soviet period. So, in one of the numerous publications on this subject, the author writes: "... the daughter of my friends (she is 14) is studying in the UK, her uniform is obligatory (as in all high level schools, these are traditions that have been developed over the centuries). And the girl (teenager) is proud of her uniform... " [39]. However, the opinions of teenage readers do not coincide with the author.

In one of the comments (errors in the original text were deliberately saved) we read: "Yes, it (a uniform) ruins our lives! What the hell should we all look the same? We would like to dress casually, and do not want to obey school rules. Autumn or spring, I'd like to wear my ripped jeans, hoodies and other stuff. We look like morons in these grey loose-fit trousers and soft pink and blue blouses of nasty shades".

It should be noted that the image of an educational institution has been transformed from a "temple of science" to a service industry institution, with respect to this concepts such as competitiveness, market segment, educational service, and educational product are increasingly used. Accordingly, the status of a teacher-mentor has changed to the status of a support staff, and students are categorized as consumers of educational services, clients, and the client is always right in the market conditions.

\section{Conclusions}

Media literacy gives people an understanding of how media texts, which are part of everyday life, help the knowledge of the world in social variations, economic and political position. The hermeneutic analysis described in the article has revealed a change in the educational paradigm in modern Russia, which caused a change in the roles of participants in the educational process reflected in the media texts of all genres and forms published on the Internet. We consider a hermeneutic analysis as theory and general rules for interpreting texts, a critical and thoughtful attitude towards media with the goal of education and knowledge dissemination to people who will be able to express their own judgments based on the information received. It gives them the opportunity to use the information, to analyze it, to identify economic, political, social and cultural interests that are associated with it. A hermeneutic analysis of school and student media texts published on the websites of Teacher's Newspaper, Newtonew, ShkolaZhizni.ru, Our Youth, studroom.ru, etc., from 1995 to 2019 has led to conclusion that the image of school and university as educational institutions, the images of schoolchildren, students, teachers of secondary and higher schools in the media texts of different Internet resources are identical on inside, but differ on outside. The same historically, culturally and socially conditioned problems in education are presented in literary Russian on the websites of official media (for example, Teacher's newspaper), with the widespread use of youth student slang it is not always competent in comments and personal blogs (for example, in studroom .ru) and in the "language of the bastards" on marginal sites that deny the values and taboos of both the real and virtual worlds (for example, udaff.com).

The Internet has become an integral part of the educational process at school and university, which necessitated changes in the systems of general and professional education of the state, and this in turn has led to a change in the role and status of the teacher and student in the educational process.

Among the main components of the picture of Russian education in the last two decades, the following can be distinguished:

- there is a bias towards material values with the loss of spiritual values among young people;

- there is an active search for a new value system;

- a drop in the level of education in schools occurs;

- maintaining the prestige of higher education is in full swing; 
- commercialization of the educational sphere, in the process of which education is lost, is considered as a part of the educational process;

- the backlog of schools and universities from the real needs of society and the state is obvious;

- the low status of the profession of teacher has been proved.

The picture of the educational world in the past two decades has been drawn by the media on the global network mainly in dark colors. However, there are positive examples in which one wants to see a future trend and hope that editors of school and student media will hear one of the founders of the educational media resource Newtonew and the author of the project Interesting Schools of Russia, Evgeny Smirnov [40], who urges his colleagues to stop publishing nasty headlines and start telling amazing stories about education, about what is good now and what will happen in the future. But, as Albus Dumbledore (one of the main characters of Harry Potter saga) said: "Happiness can be found even in dark times, if you do not forget to turn on the light".

\section{REFERENCES}

[1] T.V. Korsakova. E.A. Makarova, E.L. Makarova. The role of globalization and integration in interdisciplinary research and education development. Journal of History Culture and Art Research, 8(1), 2019, 111-127. Online available from http://dx.doi.org/10.7596/taksad.v8i1.1957

[2] Russian Pedagogical Encyclopedia. T. 1 / Ch. ed. V.V. Davydov. M.: Big Russian Encyclopedia, 1993. p. 555.

[3] L. Masterman. Teaching the media. Routledge, London. 1985. 341 .

[4] International Encyclopedia of the Social \& Behavioral Sciences. 2001. p. 9494

[5] U. Pertseva, M. Khaliullina. Integration of media education in higher education system. Media education: experience and prospects. Materials of XXV All-Russian Scientific and Practical conference of researchers and teachers of journalism, advertising and public relations "Problems of mass communication" - Voronezh: Quarta, 2016. 149 .

[6] A. Sayer. Realism and Social Science. Sage, London. 2000. 224.

[7] N. Tucker. Understanding the mass media. Cambridge University Press, Cambridge. 1966. 212.

[8] A.A. Machenin. Media-educational recommendations for organization of advertising's media filming process. Sign: media education problem area. 2015. 110-116.

[9] Y.V. Soldatkina. The media image of teacher in contemporary media: the main themes and factors of its transformation. Theoretical and Practical Issues of Journalism, 2016. 5. 2. 261-277.
[10] A.Y. Shahanskaya. Comparative Analysis of the Evolution of the Image of the Teacher in the Soviet and Russian Posters and Professional Photos. Ministry of Education Journal. 2017. 4(1). 47-61.

[11] A.A. Machenin. Image of a school teacher in the reflection of TV / film / Internet media space. Media Education. 2016. 3. 23-48.

[12] C.M. Worsnop. Screening Images: Ideas for Media Education. Second Edition. Mississauga: Wright Communication. 1999. 199.

[13] J. Hartley. Communication, Cultural and Media Studies: The Key Concepts. London - New York. Psychology Press. 2002. 262.

[14] M.D. Griffiths. The Role of Context in Online Gaming Excess and Addiction: Some Case Study Evidence. International Journal of Mental Health and Addiction. 2010. 8(1). 119-125.

[15] E.A. Makarova, E.L. Makarova. Blending pedagogy and digital technology to transform educational environment. International Journal of Cognitive Research in Science, Engineering and Education (IJCRSEE). 2018. 6. 2. 57 -65 . Online available from doi:10.5937/ijcrsee $1802057 \mathrm{M}$

[16] F. Schleiermacher. Hermeneutik und Kritik. Frankfurt. M.: Suhrkamp. 1995.

[17] H-G. Gadamer. Towards a phenomenology of ritual and language, in Lawrence Kennedy Schmidt (ed.). Language and Linguisticality in Gadamer's Hermeneutics. Lexington Books. 2000. p. 30.

[18] J. Hans. Hans-Georg Gadamer and Hermeneutic Phenomenology, Philosophy Today. 22. 1978. 3-19.

[19] H. Turk. Wahrheit oder Methode? H.- G. Gadamers "Grundzüge einer philosophischen Hermeneutik", in: H. Birus (Hg.): Hermeneutische Positionen. Schleiermacher Dilthey - Heidegger - Gadamer, Göttingen. 1982. 120-150.

[20] A.V. Fedorov, A.A. Levitskaya, I.V. Chelysheva, O.I.Gorbatkova, G.V. Mikhaleva, L.N. Seliverstova. School and university in the mirror of American, British, French and German movies. Moscow: ICO Information for All. 2018. 100.

[21] A.A. Levitskaya, L.N. Seliverstova. An analysis of german-language media texts on topics involving school and university. Communication Today. 10. 1. 2019. 20-39.

[22] A.A. Machenin. Image of a school teacher in the reflection of TV / film / Internet media space. Media Education. 2016. 3. 23-48.

[23] S.P. Rubtsova. Hermeneutic analysis of the novel in verses of A.S. Pushkin's "Yevgeny Onegin". Bulletin of Voronezh State University. Series: Philosophy. 2014. 3 (13). 71-84.

[24] S.B. Tsymbalenko. The younger generation in the Russian information space of the XXI century. Media, Information, Communication. 2012. №4. Online available from: http://mic.org.ru/2012g/2-nomer-2012/117-podrastayushch ee-pokolenie-v-rossijskom-informatsionnom-prostranstvekhkhi-veka 
[25] V. Galkina Are you getting wild? // Teacher's newspaper. 1995. No 46 from 14.11.1995. Online available from: http://www.ug.ru/archive/ug/1995/46

[26] N.V. Kofyrin. Generation of youth of the XXI century. 2014. Online available from http://www.liveinternet.ru/community/1272263/post32941 6552

[27] B. Chernov. Left in the cold. To the army. Teacher's newspaper. 1995. No 46 from 11/14/1995. Online available from http://www.ug.ru/archive/ug/1995/46

[28] M. Kushnir. USE - the apotheosis of the educational pipeline. Online available from https://newtonew.com/school/no-exams

[29] L. Shirshova. Why do we raise a generation of dependent children. 2017. Online available from https://newtonew.com/school/pochemu-myrastim-po kolenie-nesamostoyatelnyh-detey

[30] V. Brovin How I taught at the university and almost went crazy. 2016. Online available from http://disgustingmen.com/spokoyno-ya-sam/thuglifeteacher

[31] S. Ivanova. And I'm going for a good mood, for hope, faith and love ... Teacher's Newspaper. 1995. No 46. Online available from http://www.ug.ru/archive/ug/1995/46

[32] Pestrikov R. Finding Filippok or Why will not Lomonosovs disappear in the Russian village. Teacher's Newspaper. 2004. No 36. 2004. Online available from http://www.ug.ru/archive/ug/2004/36

[33] History lessons: how to tell children about recent events in the life of the country? Teacher's newspaper. 2017. No 30. Online available from http://www.ug.ru/archive/7089

[34] E. Denisova-Schmidt. Corruption in Russian Higher Education, Russian Analytical Digest №191, St. Gallen/Chestnut Hill, MA , 2016 Online available from http://www.css.ethz.ch/content/dam/ethz/special-interest/g ess/cis/center-for-securities-studies/pdfs/RAD191.pdf

[35] V. Bezborodov. The Lost Generation. 2014. Online available from http://politrussia.com/society/ne-poteryannoe-pokolenie-4 83.

[36] L. Kononenko The main values of modern youth - comfort and tranquility. Teacher's Newspaper. 2017. No 20 Online available from http://www.ug.ru/article/972

[37] S.V. Ivanova , O.E. Artyomova. Perception routing and persuasion potential of the political internet media text Political linguistics 2013. 3 (25). 28-36.

[38] School of the 90s: education in the struggle for survival. love90.org. Online available from http://love90.org/love90/shkola-90-x-obrazovanie-vborbeza-vyzhivanie

[39] N. Protsenko. Why do I need a school uniform? School. Life.ru. Online available from https://shkolazhizni.ru/school/articles/24060

[40] E. Smirnov. Fantastic schools and those who live in them. 2017. Online available from https://newtonew.com/editorial/fantastic-schools 